\begin{tabular}{c} 
International Journal of Biological Research, 3(2) (2015) $76-81$ \\
International Journal of Biological Research \\
SPC \\
Journal home page: $\begin{array}{c}\text { www.sciencepubco.com/index.php/IJBR } \\
\text { doi: } 10.14419 / i j b r . v 3 i 2.5323 \\
\text { Research Paper }\end{array}$ \\
\hline
\end{tabular}

\title{
Presence and antibiotic susceptibility of Listeria monocytogenes in retail meat and meat products
}

\author{
Yusuf Dogruer $^{1}$, Nihat Telli ${ }^{2}$, A. Ezgi Telli ${ }^{1}{ }^{*}$, Ahmet Güner ${ }^{1}$ \\ ${ }^{l}$ Selcuk University, Faculty of Veterinary Medicine, Department of Food Hygiene and Technology, Konya/TURKEY \\ ${ }^{2}$ Selcuk University, Vocational School of Technical Sciences, Department of Food Technology, Konya/TURKEY \\ *Corresponding author E-mail: ezgiyilmaz@selcuk.edu.tr
}

\begin{abstract}
In this study total of 200 samples including red meat, ready to eat meat (RTE) and traditional red meat products were taken from butcher shops and supermarkets and analyzed for the presence of L. monocytogenes. Presence of Listeria spp. was investigated with cultural and PCR methods. Susceptibility of the isolates to 18 antibiotics were determined by disk diffusion method.

19 out of 200 samples $(9.5 \%)$ were found to be contaminated with Listeria spp. The isolates were identified as L.monocytogenes, L. innocua, L. seeligeri, L. welshimeri, L. ivanovii; $22.10 \%, 55.79 \%, 11.58 \%, 6.32 \%, 4.21 \%$ respectively. L. monocytogenes were isolated from meat pieces (2/40), minced meat (3/40) and hamburger $(1 / 20)$.

All of the L. monocytogenes isolates were susceptible to three antibiotics (Amoxycillin/Clavulonic acid, Sulphamethoxazole/ Trimethoprim and Vancomycin) and resistance to one antibiotic (Clindamicin).

As a result, it was evaluated that minced meat and meat pieces was the highest rate $(83.3 \%, 5 / 6)$ of contamination with $L$. monocytogenes. Determination of non-pathogenic Listeria spp. is found to be important because of the indicator of L. monocytogenes. Hereby, the results presented in this study indicated the potential risk of raw meat and meat products on infection with L. monocytogenes.
\end{abstract}

Keywords: Antibiotic Susceptibility; L. monocytogenes; Meat; PCR; Public Health.

\section{Introduction}

Listeria monocytogenes is a ubiquitous microorganism which is responsible for listeriosis that can lead to a rare but severe disease in humans, who can become infected by ingesting contaminated food products. It would have a high risk factor in dairy, meat, fish and vegetables. Because of its unique feature, listeriosis represents a considerable public health concern with its high mortality rate (Wan Norhana et al. 2010a). Although it can occur in healthy humans, listeriosis mainly affects the elderly, immunocompromised persons, pregnant women and newborns, with a high rate of mortality (20-30\%) (Magalhaes et al. 2014).

According to the data of EFSA (2012), the most widely affected population group is elderly people who are over the age of 65 years $(60,2 \%$ of cases) and the mortality rate is $17.0 \%$. The individuals who have an underlying condition have a majority of listeriosis because of suppression of their T-cell-mediated immunity (Farber \& Peterkin 1991).

Raw meat is considered as a significant source in transmission of L. monocytogenes from animals to humans. Meat and meat products are exposed to contamination during especially processing, transporting and storage stages. Foong \& Dickson (2004), observed that the adhesion of L. monocytogenes to the surface of different kind of ready to eat meat products occurs in a short period as five minutes. Eventhough there are many preservation methods (eg. sterilization, low temperature) that are proven for safety, the ubiquitous nature and ability to grow at refrigerated temperature of the microorganism makes it a significant hazard to the safety of ready-to-eat (RTE) meat products. L. monocytogenes contamination in RTE meat mainly occurs at the slicing and packaging stages after cooking (Güven \& Patır 1998, Farber et al. 2007). Martins \& Germano (2011), stated that ready-to-eat sliced foods may pose a higher risk for foodborne diseases, and presence of L. monocytogenes is the major concern. In European Union (EU) the level proportion of samples for ready to eat (RTE) meat products, exceeding level for $L$. monocytogenes is $100 \mathrm{cfu} / \mathrm{g}$ (EFSA 2013). Murphy et al. (2005) stated that RTE meat products could be well contaminated with $L$. monocytogenes during post-processing steps such as slicing, peeling, and packaging.

Isolation of L. monocytogenes from meat and meat products was recorded previously by many investigators (Vitas et al. 2004, Farber et al. 2007, Yan et al. 2010, Marian et al. 2012, Gomez et al. 2014).

L. monocytogenes is naturally susceptible to a wide range of antibiotics and these are especially effective on Gram-positive bacteria (Charpentier \& Courvalin 1999). The Comité de l'Antibiogramme de la Société Française de Microbiologie (CASFM) (CA-SFM 2010) and the National Reference Center for Listeria (NRCL) (Lecuit \& Leclercq 2012) indicated that human strains of L. monocytogenes are sensitive to a wide range of antibiotics. These are including penicillin, ampicillin, amoxicillin, gentamicin, erythromycin, tetracycline, rifampicin, cotrimoxazole, vancomycin and imipenem according to their data. Furthermore, it was stated by Lecuit \& Leclercq, (2009) that most strains of $L$. monocytogenes have a natural resistance to fluoroquinolones, third and fourth generation of cephalosporins and also to fosfomycin, oxacilin and licosamides.

On the other hand, there is an increasingly serious concern 
because of jeopardizing the spread of microorganisms that have resistance to appropriate and effective first choice antibiotics (Gomez et al. 2014). Increasing the rate of antimicrobial use in developing countries induced to increase the resistance in wide range of bacteria (Levy \& Marshall 2004). Spread of antimicrobial resistance between countries and continents has been increasing because of the global trade and travel around the world. Therefore, antimicrobial resistance is agreed as a global public health concern (Doyle et al. 2013). Moreover, the studies performed on circulating strains of L. monocytogenes by the NRCL with human strains and with foodstuff strains did not show an increase in resistance to antibiotics (Granier et al. 2011).

The purpose of this study was to determine the presence of $L$. monocytogenes in raw meat, Turkish traditional meat products, (pastrami, Turkish fermented sausage, Inegol Meatball) and RTE meat products collected from butcher's shop and retail markets and antibiotic resistance pattern to various antibiotics that are widely used in human medicine.

\section{Materials and methods}

\subsection{Samples}

200 samples of raw meat and RTE-meat products were sampled from butcher shops and supermarkets. The samples were transferred into sterile plastic bags and transported in icebox to the laboratory within two to $4 \mathrm{~h}$ of sampling.

\subsection{Isolation and identification}

Food and Drug Administration (FDA) method was used for isolation and identification of $L$. monocytogenes in this study as described by (Hitkins 2002). Briefly, $25 \mathrm{~g}$ of samples were added to $225 \mathrm{ml}$ of Listeria Enrichment Broth (Merck-KGaA 64271 Darmstadt, Germany-1.11951) as the first enrichment culture in stomacher bag and were homogenized in a stomacher and incubated for $4 \mathrm{~h}$ at $30{ }^{\circ} \mathrm{C}$. Listeria - Selective Enrichment Supplement (Merck-1.11781)was added to the enrichment broth. After 44 hours, after incubation, a loopful of the enriched culture was streaked onto Oxford Listeria Selective Agar Base (Merck1.07004) containing Oxford selective supplement (Merck1.07006) and incubated for another $24-48 \mathrm{~h}$ at $37{ }^{\circ} \mathrm{C}$. Five of the presumptive colonies from Oxford Listeria selective agar were drawn on Tryptone Soya Yeast Ekstract Agar (Merck-1.03753) and incubated at $37{ }^{\circ} \mathrm{C}$ for $24 \mathrm{~h}$. The following biochemical tests were carried out from the colonies growing on TSA (morphology using Gram staining, catalase, oxidase, urea, motilitiy in SIM Medium, MR-VP, hemolysis on blood agar, CAMP Test and fermentation of glycose, esculine, mannitole, xylose, rhamnose and maltose) and then confirmed with Polymerase Chain Reaction (PCR).

\subsection{Confirmation of $L$. monocytogenes isolates by poly- merase chain reaction}

Following biochemical testing, the presumptive isolates were subjected to PCR analysis to confirm whether they were $L$. monocytogenes. A commercial DNA extraction kit (Fermentas, $\neq \mathrm{K} 0512$ Lot:00071751) was used on samples according to the manufacturers' instructions. In this study, a classical PCR was performed to detect the presence of $L$. monocytogenes.

The following oligonucleotide primers were used: F: 5'- CAT TAG TGG AAA GAT GGA ATG -3' and B: 5'- GTA TCC TCC AGA GTG ATC GA -3; based on the sequence of hly (732 bp) gene to detect $L$. monocytogenes according to Gouws and Liedemann (2005).

The amplification was carried out in DNA termalcycler using the following conditions: first, the denaturation step at $80{ }^{\circ} \mathrm{C}$ for 10 min then, $94{ }^{\circ} \mathrm{C} 3 \mathrm{~min}$. followed by 30 cycles consisting of: denaturation at $94{ }^{\circ} \mathrm{C}$ for $30 \mathrm{~s}$, annealing at $55{ }^{\circ} \mathrm{C}$ for $30 \mathrm{~s}$, extension at $72{ }^{\circ} \mathrm{C}$ for $30 \mathrm{~s}$. Final extension was carried out at 72 ${ }^{\circ} \mathrm{C}$ for $2 \mathrm{~min}$. The amplified DNA was analyzed by gel electrophoresis on a $1 \%$ agarose gel stained with ethidium bromide. A100bp ladder (Fermentas) was used as a reference marker. The agarose gel was viewed using UV transillumination.

\subsection{Antibiotic susceptibility of the isolates}

The antibiotic susceptibility pattern of 6 isolates of $L$. monocytogenes isolated from meat and meat products to antibiotics used widespread as veterinary and human medicine was determined by standard disk diffusion method. The antibiotics included Amikacin $(30 \mu \mathrm{g})$, Amoxycillin/Clavulonic acid(30 $\mu \mathrm{g})$, Ampicillin $(10 \mu \mathrm{g})$, Cefixime $(5 \mu \mathrm{g})$, Cephalotin $(30 \mu \mathrm{g})$, Chloramphenicol $(30 \mu \mathrm{g})$, Ciprofloxacin $(5 \mu \mathrm{g})$, Clindamycin $(2 \mu \mathrm{g})$, Erythromycin $(15 \mu \mathrm{g})$, Gentamicin $(10 \mu \mathrm{g})$, Kanamycin $(30 \mu \mathrm{g})$, Nalidixic acid $(30 \mu \mathrm{g})$, Oxacillin $(1 \mu \mathrm{g})$, Penicillin

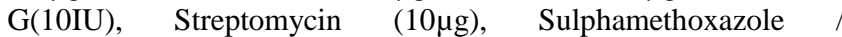
Trimethoprim $(25 \mu \mathrm{g})$, Tetracycline $(30 \mu \mathrm{g})$, Vankomycin $(30 \mu \mathrm{g})$. Disk diffusion susceptibility tests were carried out according to Bauer et al (1996) using Mueller Hinton agar (MH agar, Oxoid, CM337B). Plates were incubated at $37{ }^{\circ} \mathrm{C}$ for $18 \mathrm{~h}$. Zones of growth inhibition were evaluated according to the Clinical and Laboratory Standards Institute (CLSI) standard (CLSI 2009).

\section{Results}

In the study, 200 food samples included raw meat pieces, minced meat, pastrami, hamburger meatball, Inegol meatball, salami, sausage and Turkish Fermented Sausage (sucuk) were investigated for the presence of Listeria spp. Listeria spp. were recovered from 19 samples $(9.5 \%)$. The isolates were identified as $L$. innocua, $L$. seeligeri, L. welshimeri, L.monocytogenes, L. ivanovii; $55.79 \%$, $22.10 \%, 11.58 \%, 6.32 \%, 4.21 \%$ respectively. L. monocytogenes were isolated from meat pieces $(2 / 40)$, minced meat $(3 / 40)$ and hamburger $(1 / 20)$.

Listeria spp. was found contaminated with seven of 40 minced meats $(17.5 \%)$, three of 20 pastrami $(15 \%)$, four of 40 raw meat pieces (10\%), two of 20 hamburger meatballs $(10 \%)$, one of the 20 Inegol meatballs (5\%), one of the 20 salami samples $(5 \%)$ and one of the 20 Turkish Fermented Sausage (5\%) (Fig 1).

Previous studies showed that contamination rates of meat pieces and minced meat with Listeria spp.,was with varying values in the range of $0-97 \%$. Our results were in accordance with many other studies (Fantelli \& Stephen 2001, Gudbjörnsdot et al. 2004, Vitas et al. 2004, Barros et al. 2007, Jalali \& Abedi 2008) especially with raw meat pieces and minced meat contamination. In a similar study, Uyttendaele et al (1999) stated that contamination rates of L. monocytogenes with raw meat products $(13.71 \%)$ were significantly higher than heat treatment meat products $(4.90 \%)$.

According to Martins \& Germano (2011), it is accepted that the major cause of outbreaks is contamination of foods that may occur at any stage of processing and post-processing. The investigators additionally stated that the most important recontamination sources are the ingredients that raw or unthreated that are added to products at post-process stage; contact surfaces and environments; and improper hygiene on management and/or packaging stages of production line. In a study about contamination of $L$. monocytogenes after process of sliced salami, indicated that the factors of retail and domestic storage such as storage temperature, packaging conditions, and the initial number of contamination were highly dependent on the kinetics of the bacterium (Gounadaki et al. 2007). 


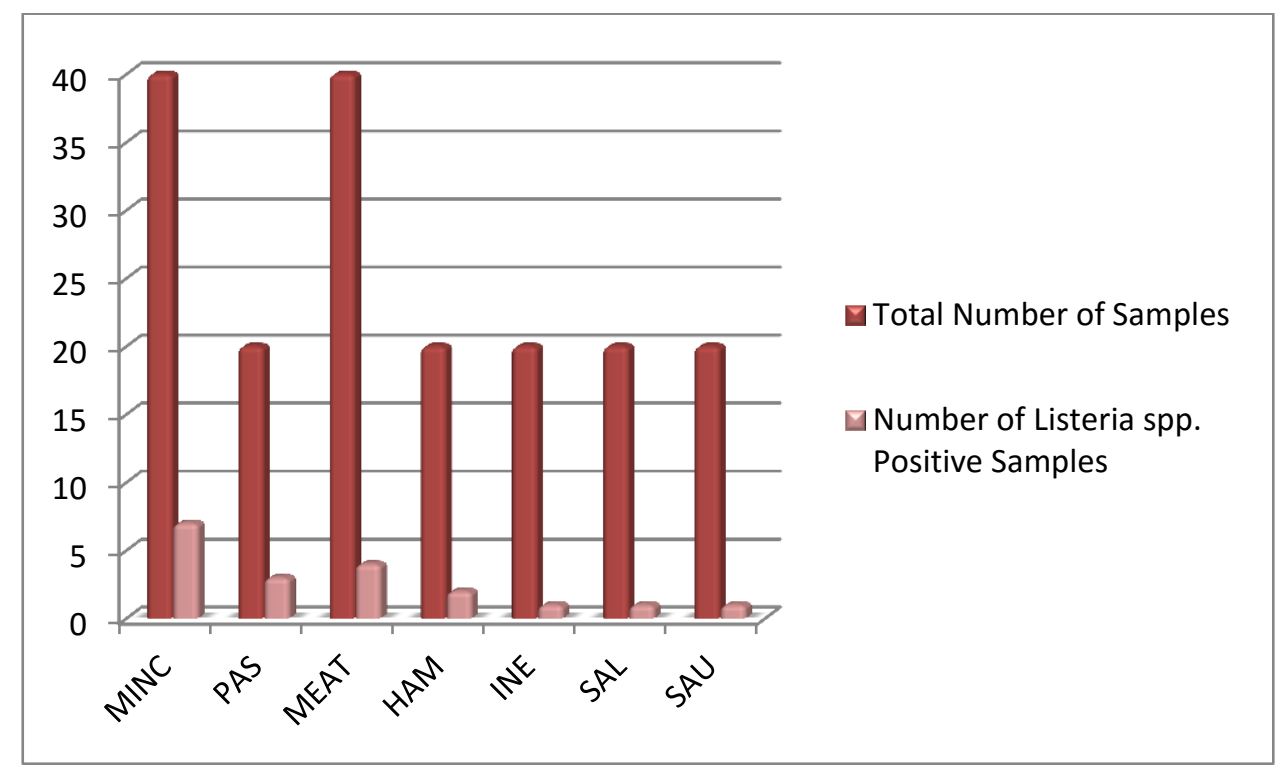

Fig. 1: Rates of the Samples Contaminated with Listeria Spp.

MINC:Minced Meat; PAS:Pastrami; MEAT:Meat Pieces; HAM:Hamburger; INE:Inegol Meatball; SAL:Salami; SAU:Turkish Fermented Sausage

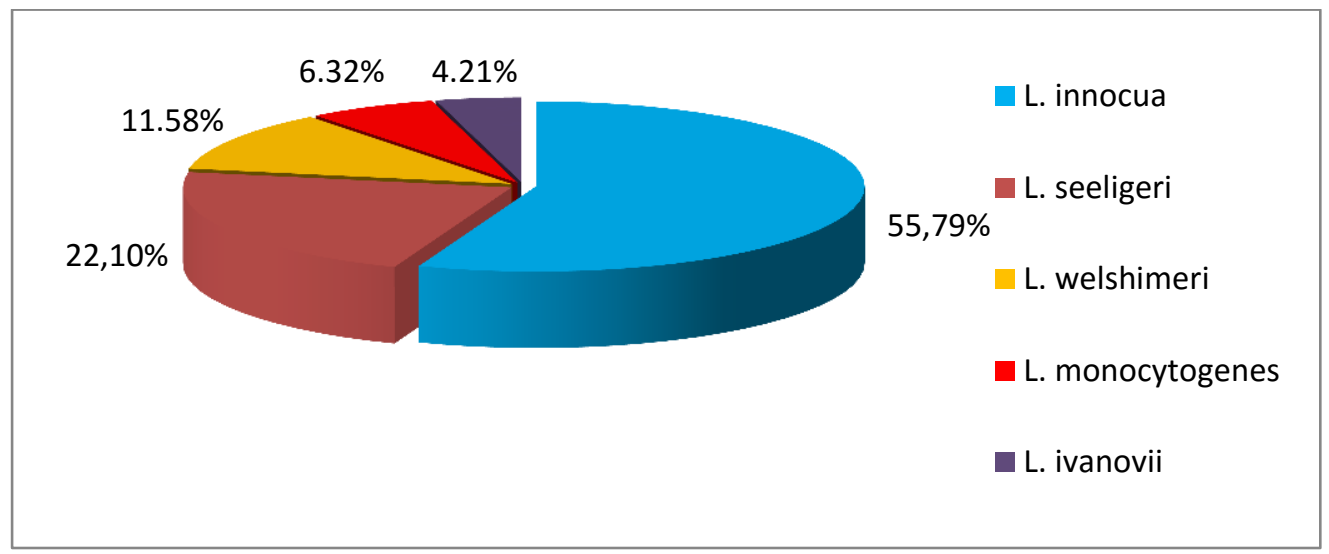

Fig. 2: Rate of Isolates According to Listeria Species

In the analyzed groups, minced meat was found in the most frequently contaminated food category $(17,5 \%$ positive). In the same way Soyutemiz (2001), claimed that the level of contamination with Listeria spp in minced meat is higher than the carcass or meat. This is because processing meat to minced meat significantly increases the contamination. The ubiquiter feature (Pociecha et al. 1991, Uhitil et al. 2004) and ability of biofilm formation on different surfaces (eg., stainless steel, glass, wood, plastic, cardboard) of the bacteria (Senczek et al. 2000, Lado \& Yousef 2007, Montanez-Izquierdo et al. 2011, Galvao et al. 2012) promotes this statement. As a result of many researches by many investigators (Soyutemiz 2001, Schlegelova et al. 2004, Şireli \& Erol 2007), it was thought that isolating high levels of Listeria spp. in raw red meat pieces and minced meat is because of inadequate sanitation and hygienic conditions in slaughterhouses, tools, equipment and machines used for meat preperation and personnel-sourced cross-contaminations.

In the similar studies carried on meat and meat products, contamination rates with Listeria spp. were found to vary in the range from $6.7 \%$ to $90 \%$ (Arumugaswamy et al. 1994, Guven \& Patır 1998, Vitas et al. 2004, Berktaş et al. 2006, Barros et al. 2007, Çolak et al. 2007, Jalali \& Abedi 2008). Jalali \& Abedi (2008), 18,18\% of hamburger meatballs $6.7 \%$ of other kind of meat products in Iran, Barros et al (2007) 9 of 10 fresh sausages in Brazil, Vitas et al (2004) 72 of $396(18,2 \%)$ ready to eat meat, 184 of $295(\% 62,3)$ raw meat in Spain have found contaminated with Listeria spp. Arumugaswamy et al (1994) found that six of
12 beef meat was contaminated with $L$. monocytogenes in Malaysia. Güven \& Patır (1998), 13 of 80 (16,3\%) sucuk samples in Elazıg/Turkey, Berktaş et al (2006) 19 of 25 (76\%) sucuk samples, four of 25 (\%16) salami samples, 11 of $25(44 \%)$ sausage samples and eight of $25(32 \%)$ pastrami samples in Van/Turkey, Çolak et al (2007), 63 of 300 (21 \%) Turkish Style Fermented Sucuk have found contaminated with Listeria spp.

A co-contamination with different species of Listeria spp. was determined in several samples. The most frequent combination was L. monocytogenes-L. innocua. Milillo et al. (2012) stated that $L$. monocytogenes and $L$. innocua has a close genetic relationship and $L$. innocua was sometimes used as surrogate for $L$. monocytogenes. According to Norwood \& Gilmour (2001) due to their similarity, they may compete for available nutrients and attachment sites on surfaces resulting in a decrease of either species compared to their respective populations in pure biofilms. The present results are not in agreement with Awaisheh (2010) who found that the prevalence rate of isolated $L$. innocua and $L$. welshimeri were the most and least frequently isolated from 56 beef and 36 poultry samples.

\subsection{Confirmation of $L$. monocytogenes isolates by poly- merase chain reaction}

The results obtained by the standard conventional bacteriological method are consistent with those obtained by PCR technique (Fig $3)$. 


\subsection{Antibiotic susceptibility of isolates}

The results of the susceptibility of six L. monocytogenes isolates to 18 tested antibiotics showed that all of the isolates were susceptible to three antibiotics (Amoxycillin/Clavulonic acid,
Sulphamethoxazole/ Trimethoprim and Vancomycin) and resistance to one antibiotic (Clindamicin).The isolates displayed some differences in antimicrobial susceptibility from that of the reference strain (Table 1).

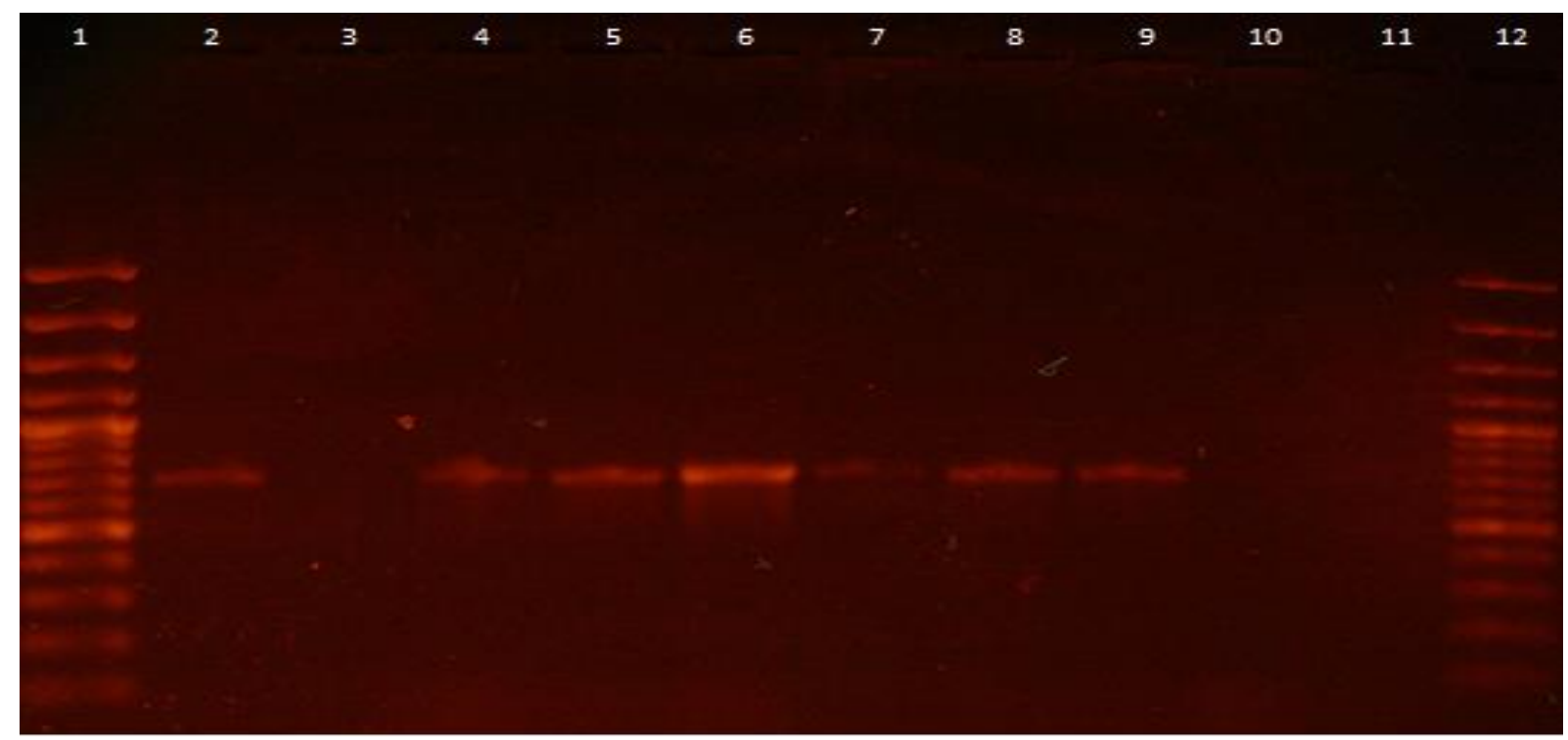

Fig. 3: Confirmation of Isolates by PCR. 1 and 12: Markers (100 Bp); 2: Positive Control 3: Negative Control 4-9: Positive Isolates

Table 1: Antibiotic Susceptibility of Isolates

\begin{tabular}{|c|c|c|c|c|c|c|c|c|}
\hline Antibiotic & Concentration & ATCC & 1 & 2 & 3 & 4 & 5 & 6 \\
\hline Amikasin & $30 \mu \mathrm{g}$ & $\mathrm{S}$ & $\mathrm{S}$ & $\mathrm{S}$ & $\mathrm{M}$ & $\mathrm{R}$ & $\mathrm{R}$ & $\mathrm{S}$ \\
\hline Amoxycillin/Clavulonic acid & $30 \mu \mathrm{g}$ & $S$ & $S$ & $S$ & $\mathrm{~S}$ & $\mathrm{~S}$ & $\mathrm{~S}$ & $\mathrm{~S}$ \\
\hline Ampicillin & $10 \mu \mathrm{g}$ & $\mathrm{R}$ & S & $S$ & S & $\mathrm{R}$ & $\mathrm{R}$ & $\mathrm{S}$ \\
\hline Cefixime & $5 \mu \mathrm{g}$ & $\mathrm{R}$ & $\mathrm{R}$ & S & $\mathrm{R}$ & $\mathrm{R}$ & $\mathrm{R}$ & $\mathrm{R}$ \\
\hline Cephalotin & $30 \mu \mathrm{g}$ & $S$ & $S$ & $\mathrm{~S}$ & $\mathrm{~S}$ & $\mathrm{R}$ & $\mathrm{R}$ & $\mathrm{S}$ \\
\hline Chloramphenicol & $30 \mu \mathrm{g}$ & $S$ & $S$ & $\mathrm{~S}$ & $\mathrm{~S}$ & $\mathrm{R}$ & $\mathrm{R}$ & $\mathrm{S}$ \\
\hline Ciprofloxacin & $5 \mu \mathrm{g}$ & $\mathrm{R}$ & M & $\mathrm{S}$ & M & M & $\mathrm{S}$ & $\mathrm{S}$ \\
\hline Clindamycin & $2 \mu \mathrm{g}$ & $\mathrm{R}$ & $\mathrm{R}$ & $\mathrm{R}$ & $\mathrm{R}$ & $\mathrm{R}$ & $\mathrm{R}$ & $\mathrm{R}$ \\
\hline Gentamicin & $10 \mu \mathrm{g}$ & S & M & $\mathrm{S}$ & $\mathrm{S}$ & $\mathrm{R}$ & $\mathrm{R}$ & $\mathrm{S}$ \\
\hline Kanamycin & $30 \mu \mathrm{g}$ & S & $\mathrm{S}$ & $\mathrm{S}$ & M & $\mathrm{R}$ & $\mathrm{R}$ & S \\
\hline Nalidixic acid & $30 \mu \mathrm{g}$ & $\mathrm{R}$ & $\mathrm{R}$ & M & $\mathrm{R}$ & $\mathrm{R}$ & $\mathrm{R}$ & $\mathrm{R}$ \\
\hline Oxacillin & $1 \mu \mathrm{g}$ & $\mathrm{R}$ & $\mathrm{R}$ & $\mathrm{S}$ & $\mathrm{R}$ & $\mathrm{R}$ & $\mathrm{R}$ & M \\
\hline Penicillin G & $10 \mathrm{IU}$ & $\mathrm{R}$ & S & $S$ & S & $\mathrm{R}$ & $\mathrm{R}$ & S \\
\hline Streptomycin & $10 \mu \mathrm{g}$ & S & M & M & $\mathrm{R}$ & $\mathrm{R}$ & $\mathrm{R}$ & $\mathrm{S}$ \\
\hline Sulphamethoxazole/Trimethoprim & $25 \mu \mathrm{g}$ & $S$ & $\mathrm{~S}$ & $\mathrm{~S}$ & S & S & $\mathrm{S}$ & $\mathrm{S}$ \\
\hline Tetracycline & $30 \mu \mathrm{g}$ & S & S & $\mathrm{S}$ & $\mathrm{S}$ & $\mathrm{R}$ & $\mathrm{R}$ & $\mathrm{S}$ \\
\hline
\end{tabular}

S: Sensitive. R: Resistant. M: Moderate Level.

1: Isolate of Minced Meat (1), 2: Isolate of Minced Meat (2), 3: Isolate of Minced Meat (3), 4: Isolate of Cubed Meat (1), 5: Isolate of Cubed Meat (2) 6: Isolate of Hamburger Meatball

It's known that L. monocytogenes have developed many kind of pathways and modifications as acquiring or transfering antibiotic resistances genes from plasmid and transpoosons of other bacteria (Pesavento et al. 2010). Most of the isolates in this study was sensitive to the major classes of antibiotics used in veterinary and human medicine. It points that there was a natural, later developing or transferred resistance to certain antibiotics like Amicasin, Gentamycin, Kanamycin, Streptomycin (3 isolates); Cephalotin, Chloramphenicol, Erythromycin, Tetracycline (2 isolates).

Yan et al (2010), isolated L. monocytogenes in 90 food samples in a total of 2,177 units $(4.13 \%)$. They have identified that the isolates showed resistance to ciprofloxacin $(17.8 \%)$, tetracycline $(15.6 \%)$ and streptomycin $(12.2 \%)$ respectively. Researchers observed antimicrobial resistance against 14 antibiotics out of 18 tested. Furthermore, some of the isolates (18.9\%) were observed to show multiple resistance.

Marian et al (2012), determined the isolates from minced meat, hamburger and sucuk samples were highly resistant to Ampicillin and Penicilin G $(100 \%)$ and highly susceptible to Streptomicin $(100 \%)$
In a study Fallah et al. (2012), found that L. monocytogenes isolates obtained from raw and ready to eat poultry products were resistant to ampicillin, penicillin, fluroquinolon the tetracycline. Researchers stated that resistance to these antibiotics that frequently used in humans for treatment may create problems in public health. Aureli et al. (2003) stated that, it is an important point that to be conscious about the emergence and spread of bacterial resistance to antimicrobial agents to put into practice the surveillance systems and to build up a universal and comphrensive data on dominant cause of the diseases owing to Listeria spp. In accordance with, it's thought that emerging antimicrobial resistance of $L$. monocytogenes is an important concern to provide accurate and efficient treatment.

\section{Discussion}

Our study identifies the occurrence of Listeria spp and $L$. monocytogenes in raw meat and different kind of meat products consumed generally and traditionally in Turkey. Results of the study indicate that not only milk and dairy products but also meat and meat products may pose a risk for contamination with Listeria 
spp and L. monocytogenes. The presence of L. monocytogenes in raw meat and RTE products observed in this study, showed that they would represent a serious public health concern, when we take into account the possibility of inadequate heat treated raw meat or increase of the consumption of ready to eat meat products. Therefore, it is generally accepted that government agencies and food industries should take well-judged and corrective measures to prevent the contamination during manufacturing and they also better the monitoring systems to prevent growth of the pathogen during storage or at the retail level.

In the study, it was determined that some of the isolates have developed or acquired resistance to certain antibiotics. In accordance with, it's needed that more comprehensive and continuous surveillance systems and it should be taken into consideration that emerging antimicrobial resistance of this pathogen to impelement the appropriate and effective treatment.

\section{Acknowledgements}

This project was supported by the Scientific Research Projects Coordination Unit of Selcuk University with the project number 10401014. A part of this study was presented in 2th International Food Technology Congress 2014 in Kusadasi- TURKEY.

\section{Conflict of interest}

All the authors declare that there is no conflict of interests regarding the publication of this research article.

\section{References}

[1] Arumugaswamy RK, GRR Alib \& SNBA Hamid (1994) Prevalence of Listeria monoctogenes in foods in Malaysia. International Journal of Food Microbiology, 23(1), 117-121. http://dx.doi.org/10.1016/0168-1605(94)90227-5.

[2] Awaisheh SS (2010) Incidence and Contamination Level of Listeria monocytogenes and Other Listeria spp. in Ready-to-Eat Meat Product in Jordan. Journal of Food Protection, 73(3),535-40.

[3] Aureli, P., A.M. Ferrini, V. Mannoni, S. Hodzic, C. WedellWeergaard \& B. Oliva (2003) Susceptibility of Listeria monocytogenes isolated from food in Italy to antibiotics. Internationa Journal of Food Microbiology, 83(3),325-330. http://dx.doi.org/10.1016/S0168-1605(02)00381-1.

[4] Barros, M.A.F., A.N. Luis \& C.S. Livia (2007) L. monocytogenes:Occurrence in beef and identification of the main contamination points in processing plants. Meat Science, 76,591-596. http://dx.doi.org/10.1016/j.meatsci.2007.01.016.

[5] Bauer, A.W., M.M. Kirby, J.C. Sherris \& M. Truck (1996) Antibiotic susceptibility testing by a standardized single disk method. American Journal of Clinical Pathology, 45, 493-496.

[6] Charpentier, E \& P. Courvalin (1999) Antibiotic Resistance in Listeria spp. Antimicrobial Agents and Chemotherapy, 43, 2103-2108.

[7] Clinical and Laboratory Standards Institute (CLSI) (2009) Performance standards for antimicrobial susceptibility testing; nineteenth informational supplement. CLSI document M100-S19. Wayne, PA.

[8] Codex Alimentarius Commision (2007) Codex Alimentarius Commission Joint FAO/WHO food standard programme. Guidelines on the application of general principles of food hygiene to the control of Listeria monocytogenes in foods.

[9] Colak, H., H. Hampikyan, B. Ulusoy \& E.B. Bingol (2007) Presence of Listeria monocytogenes in Turkish style fermented sausage (sucuk). Food Control, $\quad 18, \quad 30-32$ http://dx.doi.org/10.1016/j.foodcont.2005.08.003.

[10]Comite De L'Antibiogramme De La Societe Francaise De Microbiologie Recommandations 2013. Available at: http://www.resapath.anses.fr/resapath_uploadfiles/files/Documents/20 13_CASFM.pdfAccessed on: 17 March 2014.

[11]Doyle, M.P., G. H. Loneragan, H. M. Scott \& R. S. Singer (2013) Antimicrobial Resistance: Challenges and Perspectives. Comprehensive Review Food Science and Food Safety, 12, 234- 248. http://dx.doi.org/10.1111/1541-4337.12008.
[12]EFSA (European Food Safety Authority) (2012) The European Union summary report on trends and sources of zoonoses, zoonotic agents and food-borne outbreaks in 2010. EFSA Journal, 10, 2597.

[13]European Food Safety Authority (2013) Analysis of the baseline survey on the prevalence of Listeria monocytogenes in certain readyto-eat foods in the EU, 2010-2011 Part A: Listeria monocytogenes prevalence estimates. EFSA Journal 11(6), 3241.

[14]Fallah, A.A., S.S. Saei-Dehkordi, M. Rahnama, H. Tahmasby \& M. Mahzounieh (2012) Prevalence and antimicrobial resistance patterns of Listeria species isolated from poultry products marketed in Iran. Food Control. 28, 327-332. http://dx.doi.org/10.1016/j.foodcont.2012.05.014.

[15] Fantelli, K \& R. Stephan (2001) Prevalence and Characteristics of Shigatoxin-Producing Escherichia coli and Listeria monocytogenes Strains Isolated from Minced Meat in Switzerland. International

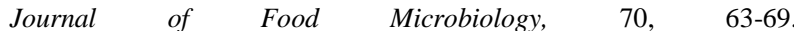
http://dx.doi.org/10.1016/S0168-1605(01)00515-3.

[16]Farber, J.M \& P.I. Peterkin (1991) Listeria monocytogenes, a FoodBorne Pathogen, Microbiological Reviews., American Society for Microbiology. 55, 476-511.

[17]Farber, J.M., F. Pagotto \& C. Scherf (2007) Incidence and Behavior of Listeria monocytogenes in Meat Products. In: Ryser ET, Marth EH, editors. Listeria, Listeriosis, and Food Safety, Third Edition, London, New York: CRC Press; 503-71.

[18]Foong, S.C \&J.S. Dickson (2004) Attachment of Listeria monocytogenes on Ready-to-Eat Meats. Journal of Food Protection, 3, 456-462.

[19]Galvao, N.N., E. Chiarini, M.T. Destro, M.A. Ferreira, \& L.A. Nero (2012) PFGE characterisation and adhesion ability of Listeria monocytogenes isolates obtained from bovine carcasses and beef processing facilities. Meat Science, 92, 635-643. http://dx.doi.org/10.1016/j.meatsci.2012.06.011.

[20] Gomez, D., E. Azon, N. Marco, J.J. Carraminana, C. Rota, A.Arino \& J. Yanguela (2014) Antimicrobial resistance of Listeria monocytogenes and Listeria innocua from meat products and meatprocessing environment. Food Microbiology, 42, 61-65. http://dx.doi.org/10.1016/j.fm.2014.02.017.

[21] Gounadaki, A.S., P.N. Skandamis, E.H. Drosinos \& G.J.E. Nychas (2007) Effect of Packaging and Storage Temperature on the Survival of Listeria monocytogenes Inoculated Postprocessing on Sliced Salami. Journal of Food Protection, 10, 2313-2320.

[22] Gouws, P.A \& I. Liedemann (2005) Evaluation of Diagnostic PCR for the Detection of Listeria monocytogenes in Food Products. Food Technology Biotechnology, 43(2), 201-05

[23] Granier, S. A., C. Moubareck, C. Colaneri, A. Lemire, S. Roussel, T.T. Dao, P. Courvalin \& A. Brisabois (2011) Antimicrobial resistance of Listeria monocytogenes isolates from food and the environment in France over a 10-year period. Applied and Environmental Microbiology, 77, 2788-2790. http://dx.doi.org/10.1128/AEM.01381-10.

[24]Güven, A \& B. Patır (1998) Elazı̆g İlinde Tüketime Sunulan Et ve Bazı Et Ürünlerinde Listeria Türlerinin Araştırılması. Turkish Journal of Veterinary and Animal Science, 22, 205-12.

[25] Hitckins, A.D (2003) L. monocytogenes. Chapter 10. In: FDA Bacteriological Analytical Manual Online. http://www.cfsan.fda.gov.

[26]Jalali, M \& D. Abedi (2008) Prevalence of Listeria Species in Food Products in Isfahan, Iran. International Journal of Food Microbiology, 122, 336-40. http://dx.doi.org/10.1016/j.ijfoodmicro.2007.11.082.

[27] Magalhaes, R., C. Mena, V. Ferreira, J. Silva, G. Almeida, P. Gibbs \& P. Teixeira (2014) Bacteria: Listeria monocytogenes In: Encyclopedia of Food Safety. Volume 1: History, Science and Methods. Ed: Yasmine Motarjemi. Elsevier, 450-461.

[28]Marian, M.N., S.M. Sharifah Aminah, M.I. Zuraini, R. Son, M. Maimunah, H.Y. Lee, W.C. Wong \& N. Elexson (2012) MPN-PCR detection and antimicrobial resistance of Listeria monocytogenes isolated from raw and ready-to-eat foods in Malaysia. Food Control, 28, 309-314. http://dx.doi.org/10.1016/j.foodcont.2012.05.030.

[29] Milillo, S.R., E.C. Friedly, J.C. Saldivar, A. Muthaiyan, C.A. O'bryan \&P.G. Crandall (2012) A review of the ecology, genomics, and stress response of Listeria innocua and Listeria monocytogenes. Critical Reviews in Food Science and Nutrition, 52,712-725. http://dx.doi.org/10.1080/10408398.2010.507909.

[30]Lecuit, M \& A. Leclercq (2012) Rapport annuel d'activité du Centre National de Référence des Listeria-Année 2011. Institut Pasteur, Paris, France. Available at: http://www.pasteur.fr/ip/resource/filecenter/document/01s-00004j03q/ra-cnr344 listeria-2011.pdf. Accessed on:12 March 2014.

[31]Norwood, D \& A. Gilmour (2001) The differential adherence capabilities of two Listeria monocytogenes strains in monoculture and multispecies biofilms as a function of temperature. Letters in Applied 
Microbiology, 33, 320-324. http://dx.doi.org/10.1046/j.1472765X.2001.01004.x.

[32]Gudbjornsdottir, B., M.L. Suihkob, P. Gustavssonc, G. Thorkelssona, S. Salob, A.M. Sjobergb, O. Niclasend \& S. Bredholte (2004) The incidence of Listeria monocytogenes in meat, poultry and seafood plants in the Nordic countries. Food Microbiology, 21, 217-225. http://dx.doi.org/10.1016/S0740-0020(03)00012-1.

[33]Lado, B.H \& A.E. Yousef. Characteristics of Listeria monocytogenes Important to Food Processors. In: Listeria, Listeriosis, and Food Safety, Elliot T. Ryser, Elmer H. Marth (eds) Third Edition. CRC Press. Boca Raton/Florida-USA. 157-215.

[34]Levy S.B \& B. Marshall (2004) Antibacterial resistance worldwide: causes, challenges and responses. Nature Medicine Supplement. 10 (12), 122-129. http://dx.doi.org/10.1038/nm1145.

[35] Martins E.A \& P.M.L. Germano (2011) Listeria monocytogenes in ready-to-eat, sliced, cooked ham and salami products, marketed in the city of São Paulo, Brazil: Occurrence, quantification, and serotyping. 22(2), 297-302. Listeria monocytogenes in ready-to-eat, sliced, cooked ham and salami products, marketed in the city of São Paulo, Brazil: Occurrence, quantification, and serotyping.

[36]Montanez-Izquierdo, V.Y., D.I. Salas-Vazquez \& J.J. Rodriguez-Jerez (2012) Use of epifluorescence microscopy to assess the effectiveness of phage P100 in controlling Listeria monocytogenes biofilms on stainless steel surfaces. Food Control, 23(2),470-477. http://dx.doi.org/10.1016/i.foodcont.2011.08.016.

[37] Murphy, R.Y., R.E. Hanson, L.K. Duncan, N. Feze \& B.G. Lyon (2005) Considerations for post-lethality treatments to reduce Listeria monocytogenes from fully cooked bologna using ambient and pressurized steam. Food Microbiology, 22, 359-365. http://dx.doi.org/10.1016/j.fm.2004.09.009.

[38]Pesavento, G., , B. Ducci, D. Nieri, N. Comodo \& A. Lo Nostro (2010) Prevalence and antibiotic susceptibility of Listeria spp. isolated from raw meat and retail foods. Food Control, 21,708-713. http://dx.doi.org/10.1016/j.foodcont.2009.10.012.

[39]Pociecha, J.Z., K.R. Smith \& G.J. Manderson (1991) Incidence of Listeria monocytogenes in meat production environments of a South Island (New Zealand) mutton slaughterhouse. International Journal of Food Microbiology, 13(4), 321-327. http://dx.doi.org/10.1016/01681605(91)90091-3.

[40] Schlegelova, J., E. Napravnikova, M. Dendisc, R. Horvathc, J. Benedik, V. Babaka, E. Klimovad, P. Navratilova \& A. Sustackova (2004) Beef carcass contamination in a slaughterhouse and prevalence of resistance to antimicrobial drugs in isolates of selected microbial species. Meat Science, 66, 557-565. http://dx.doi.org/10.1016/S03091740(03)00159-1.

[41] Senczek, D., R. Stephan \& F. Untermann (2000) Pulsed-field gel electrophoresis (PFGE) typing of Listeria strains isolated from a meat processing plant over a 2-year period. International Journal of Food Microbiology, 62, 155-159. $\quad$ http://dx.doi.org/10.1016/S01681605(00)00395-0.

[42] Soyutemiz E (2001) Survival of L. monocytogenes in Inegol Meatballs Refrigerated at $4^{\circ} \mathrm{C}$. Uludag University Journal of the Faculty of Veterinary Medicine, 27(1), 115-126.

[43]Şireli, U.T \& Erol I (1999) Hazır Kıymalarda Listeria Türlerinin Araştırılması. Turkish Journal of Veterinary and Animal Science, 23 (2), 373-80.

[44]Uhitil, S., S. Jaksic, T. Petrak, H. Medic \& L. Gumhalter-Karoly (2004) Prevalence of Listeria monocytogenes and the Other Listeria spp. in Cakes in Crotia. Food Control. 15, 213-16. http://dx.doi.org/10.1016/S0956-7135(03)00049-5.

[45] Vitas, A.I \& V.A. I. Garcia-Jalon (2004) Occurrence of Listeria monocytogenes in fresh and processed foods in Navarra (Spain). International Journal of Food Microbiology, 90, 349- 356 http://dx.doi.org/10.1016/S0168-1605(03)00314-3.

[46] Uyttendaele, M \& P.D. Troy, J. Debevere (1999) Incidence of Listeria monocytogenes in different types of meat products on the Belgian retail market. International Journal of Food Microbiology, 53, 75-80. http://dx.doi.org/10.1016/S0168-1605(99)00155-5.

[47] Yan, H., S.B. Neogi, Z. Mo, W. Guan, Z. Shen, S. Zhang, L. Li, S Yamasaki, L. Shi \& N. Zhong (2010) Prevalence and characterization of antimicrobial resistance of foodborne Listeria monocytogenes isolates in Hebei province of Northern China, 20052007. International Journal of Food Microbiology, 144(2),310-316. http://dx.doi.org/10.1016/j.ijfoodmicro.2010.10.015.

[48] Wan Norhana, M.N., S.E. Poole, H.C. Deeth \& G.A. Dykes (2010a) Control of Listeria monocytogenes with combined antimicrobials following post-process contamination and extended storage frankfurters at $4^{\circ} \mathrm{C}$ in vacuum-packages. Journal of Food Protection, $64,1722-1729$ 